\title{
The Narrative Structure Analysis of Tidung Oral Story on Alan Dundes at Tarakan City, North Kalimantan (Folklore Study)
}

\author{
Eva Apriani ${ }^{1}$ \\ ${ }^{1}$ Indonesia Education Department, Universitas Borneo Tarakan, Tarakan, Indonesia \\ *evaaprianiarie@gmail.com
}

\begin{abstract}
This research is a narrative structure of Tidung Oral Story on Alan Dundes at Tarakan City, North Kalimantan. The problem research focuses on the structure of motifeme in folklore entitled The Origin of Mount Srilaki, Betawol, Si Gumban, Putri Kumalasari, and Buluh Perindu folklore studies. The theory used uses the narrative structure theory developed by Dundes, which consists of a series of motifemes. The analysis result showed Tidung Oral Story on Alan Dundes at Tarakan City; North Kalimantan has a series of different motifeme stories (1) The Story of the Origin of Mount Srilaki consists of 10 series. (2) The Betawol story consists of 8 series. (3) The Betawol story consists of 6 series. (4) The Betawol story consists of 4 series. This study's results are expected to be useful for readers and other community members because of the story's motifeme structure. It can find out whether the story is a typology of folklore from other regions.
\end{abstract}

Keywords: Narrative Structure, Tidung Oral Stories, Folklore

\section{INTRODUCTION}

The regional culture that is spread throughout Indonesia's territory has a diversity consisting of a wealth of arts, literature, spoken language, written language, customs, social manners, and various values of life. Culture is a precious wealth because besides being a characteristic of an area, it is also a symbol of a nation's personality. One form of culture is folklore. Folklore is part of a collective culture, which is spread and passed down from generation to generation among collectives, traditionally in different versions, both in the oral form and accompanied by gestures or reminders. Folklore is part of the culture owned by each society that is passed down from generation to generation with some of the changes it brings.

One type of folklore that fills culture in Indonesia is folklore. Fable is purely oral folklore. [1] Folklore can be interpreted as a cultural expression of society through spoken language, which is directly related to various aspects of culture and the composition of the community's social values. Knowing folklore is part of understanding the history and culture of a nation. In general, folklore tells about the occurrence of various things, such as the universe's occurrence. [2] Folklore is very popular with the community because it can be used as a role model and consolation and is humorous. Therefore, folklore usually contains teachings of character or moral education and entertainment for the community.

The folklore of the Tidung tribe in North Kalimantan Province has long served as a vehicle for the inheritance of values that grow in society. Folklore is one of the cultural heritage of the Tidung community, which is of great value and has a significant role in shaping society's morale at present and in the future. Humanitarian messages in living the twists and turns of life in the story can be a basis for action and behave for the community. Folklore is used as a tool to strengthen socio-cultural values, sourced from the work of human creations from ancestral times that have been passed on to future generations from generation to generation.

Folklore as cultural wealth is a valuable form of artistic expression of the Tidungnese because it stores the cultural values of the traditional society and becomes the cultural foundation and a reflection of its community. As part of the oral tradition, the Tidung tribe is feared for its survival among its owners. Although the folklore stories 
of the Tidung tribe are still recognized in several areas in North Kalimantan, the demand for them has decreased in terms of quantity. The presence of various telecommunication media in modern life, which invade society in every culture, has led to the possibility that it will further accelerate the disappearance of the owner society's culture. Contemporary art, which is considered a mecca for the younger generation, has made regional literature, especially oral literature, displaced and even isolated in the Paguntaka world. When the oral tradition begins to be forgotten by its heir for quite a long time, it is impossible that folklore as a form of culture will disappear and experience extinction.

[3] The loss of folklore as an oral tradition impacts the disappearance of various memories of the people who owned it about the culture of the previous ancestors. Folklore which is part of cultural wealth, must be preserved and preserved. All forms of regional culture will greatly influence national culture, and vice versa, the national culture that comes from regional culture, will also greatly influence regional culture or local culture. Talking about the elements that make up literary works is an effort so that the folklore of the Tidung tribe in North Kalimantan will remain sustainable to be passed on to the next generation.

The engaging narrative prose of the Tidung tribe contains a series of historical events that form conflicts of cause and effect relationships in the story, summarized in one event after another. As a cultural heritage, the folklore of the Tidung tribe is not just narrative but is a concept of cultural heritage and a part of ourselves as social beings. [4] Folklore as oral literature does not only function as a medium of entertainment but also as a means of maintaining community norms that have a crucial role in shaping morals and being a basis for action and behavior for generations of people in North Kalimantan.

It is very worrying that Tidung's oral literature repertoire will disappear one by one due to being eroded by the telecommunications media and modern culture. Tracing the study of the narrative structure of the Tidung folklore of the Tidung tribe in North Kalima comprehensively is the essential thing in the study of literary works. The narrative text is composed of structural dyadic analogies that cannot be separated from the certainty of reading the text that is implicit in it and begins with structural reading.

Departing from the description above, research will be conducted with the title Analysis of narrative structures on oral stories of the Tidung tribe in Tarakan City, North Kalimantan. By using folklore studies. The concept developed by Dundes is used to dissect the motives that underlie a story and analyze a story unit whose elements are interrelated. [5] It is not uncommon for folk tales to have the same story pattern. In the realm of folklore research (folktales), the similarity of these patterns is called motive.

\section{METHOD}

This research includes field research. [6] This research is a qualitative ethnographic model, and data collection is done using a natural setting (natural conditions). The ethnographic approach is used to explain Tidung folklore's potentiality and its actualization in the owner's community. Thus, [7] this study's ethnographic method is used to explore the folklore of the Tidung tribe in the city of Tarakan, North Kalimantan. [8]Also, the ethnographic approach is holistic-integrative, a model approach that aims to obtain data based on the native's point of view. With this approach, it is hoped that a holistic description of the folklore text of the Tidung tribe in Tarakan City will be obtained.

Data collection techniques in this study were participant observation, recording, in-depth interviews, and note-taking. [7] Data collection techniques in oral literature can use (1) observation, (2) recording, (3) interviews, and (4) recording. With these techniques, it is hoped that more accurate data can be obtained according to the research's focus. Researchers can also carry out these techniques simultaneously by adjusting conditions in the field.

For the accuracy of the interview process with informants, researchers used instruments relevant to the study's focus and objectives. The instrument is an interview guide used as a guide for initial questions to informants in conducting interviews.

In the observation technique, three objects will be involved at once, the location where the research takes place, the actors with specific roles, and the activities of the actors who are used as research objects (Ratna, 2010: 220). Through natural observation and in-depth interviews, the data collected will be more completed. Data obtained from observations and interviews will naturally be more meaningful.

[9] [10] [11] Data analysis in this study was carried out using qualitative ethnographic techniques, starting from the data collection process until the data was collected entirely. Ethnographic qualitative data analysis is intended to describe the cultural system, especially in telling the folk tales of the Tidung tribe.

\section{RESULT AND DISCUSSION}

Based on the results of research on the Oral Story of the [12] Tidung Tribe of North Kalimantan, entitled Putri Kumala Sari and Buluh Perinduh . 4 data were obtained in the form of quotations indicating motifame which formed the following series: Task, Task Completed, Lack, Lack Liquidate. 


\subsection{The folklore motifeme entitled The Origin of Mount Srilaki}

"His mother asked Eji Essoy not to disturb any animals around the house because the animals do not disturb Eji and his mother's life."

The oral story quote above shows a motive interdiction (prohibition), which should not be done or violated by the characters in the story. From the above quote, Queen Suncu is worried about her son named Eji Essoy, who likes to fight wild animals around his house, namely a sun bear by because the quote above appears as a motive for prohibition.

"Eji Essoy forgot his mother's message not to fight with wild animals. He repeated his previous actions, fighting with a sun bear."

The quote from the oral story above is a motive violation which indicates the violation. Eji Essoy forgot about his mother's prohibition, namely not to fight with wild animals around his house. So that from this quote, the motifeme violation appears as evidence of a breach committed from the previous motifame interdiction.

"Since the incident happened again, the mother was very disappointed. The mother doesn't feed Eji."

The oral story quote above is a motive for the consequences, which states about the karma/results of the characters' actions in the story. Eji Essoy, who violated his mother's prohibition, his mother Queen Suncu, did not give Eji Essoy food as a sign of punishment for fighting with wild animals again and ignoring his mother.

"Eji Essoy feels hungry, but his mother still doesn't give him food. Then Eji Essoy left his mother by going to the forest to find food."

The quote from the oral story above is an escape motif that states the main character's attempt to escape from danger. It can also be in the form of the main character's attempt to escape from the motives for the consequences that will happen to him. The above quote shows Eji Essoy starving because of the karma he got from his actions, going to the forest looking for his food, and getting lost.

"He introduced himself by changing his name to Lin Impar. He also admits that he lives alone without a mother."

The oral story quotation above is a motifeme deceit that states the tricks committed against the characters in the story. Eji Essoy's trick against a woman who is none other than his mother by hiding his real name as Lin Impar and lying that he lived a life without having a mother so that the woman did not know that Eji Essoy was his son.
"There are deep scratch marks. Queen Suncu immediately remembered the events of many years ago, namely the little Eji Essoy, his son."

The oral story excerpt above is a motifeme deception which is a disclosure of the hoax committed. Eji Essoy's trick contained in the previous deceit's motive by hiding his real name's identity was finally discovered by Queen Sunccu, the woman he wanted to marry who was none other than his biological mother. Queen Suncu can tell from the claw scars on Eji's back while fighting a sun bear when he was a child.

The analysis results The Origin of Mount Srilaki, 10 data were obtained in quotations indicating motive which formed the following series: Interdiction, Violation, Consequences, Attempt Escape, Deceit, Deception, Task Completed, Lack, Lack Liquidate.

\subsection{Analysis of folklore motifame in the form of Betawol}

"One of the angels stayed behind because she couldn't fly without her scarf. One of the angels was left alone. Her six siblings had flown into heaven with their scarves. The remaining angel cried sadly, then Betawol came over and comforted her."

The quote from the story above is a motifeme lack liquidate, which states about a part of the folklore that indicates the motive's fulfillment. From the excerpted story above, Betawol managed to steal a shawl from one of the angels so that the angel could not return to heaven. Betawol, who was interested in the angel, approached the angel and asked her to come home.

"One-day, Betawol was visited by the customary village elder. Suggested that Betawo should immediately marry the girl because the village people thought it inadequate. Society thinks it is not suitable for a single person and an unmarried girl to live under the same roof. "

The quote from the story above is a motifame task which states about a task that the main character must carry out. In the above story, the traditional leader advises Betawol to immediately marry a girl who is none other than an angel who was stolen by Betawol so that people don't think badly of seeing women and men live in a house without any ties between husband and wife.

"Thanks to the support of the mother and traditional leader, Betawol married the angel because they had to live in one house."

The quote from the story above is motifame task completed, which states the fulfillment of the motive task. The above quotation explains that the fulfillment of the previous motive task was when the Betawol main character wanted to marry the angel after getting encouragement from the village's traditional leader and residents. 
"The community continued to insist that Dedari want to dance, so Dedari submitted a request to dance, namely asking for his shawl."

The quote from the story above raises a motifame task that states that the community ordered Dedari, the wife of Betawol, to dance to entertain the community. However, Dedari had a condition, namely asking for his shawl to return so that he would dance. It is indicated that the statement contained in the quote above is the task motive.

"Bentawol agreed to these requirements because he was fascinated by the party that was about to start."

The quote from the story above is motifame task completed, which states the fulfillment of the motifame task, as seen from the main character above who is willing to give his wife, an angel, to dance at the people's party.

From the folklore analysis results entitled Betawol, 8 data were obtained in the form of quotations indicating motifame, which formed the following series: Lack, Lack Liquidate, Task, Task Completed, Task, Task Completed, Deceit, Detention.

\subsection{Analysis of the folklore motifame entitled Si Gumban}

"Not only that, but Si Gumban also only wants to eat rice with rice that cannot be broken when processed."

The quotation from the story above is a motifame task which states the task given by the main character indirectly so that the people prepare whole rice without the slightest broken or defect. "

"So began the coffin making, the people did it not far from the shoreline, they gathered the strongest wood around their kingdom."

The quotation from the story above is a lack of liquidating moifame lack which states the previous fulfillment. The people began working on a coffin prepared to trap the arrogant King and end the wrongdoing he had done so far.

"The Gumban came to the crowd arrogantly; he also asked what the people were doing. The people answered and explained that they would make a very strong lungun, lungun which if it was covered it would not be able to open again".

The quote from the story above is a motifame deceit stating fraud against the character Si Gumban. The community explains that it will make a very strong lungun if someone can enter, but they will not come out again. The lungun referred to a coffin prepared for $\mathrm{Si}$ Gumban.

"Hearing that the people immediately told the Gumban that the lungun was made to trap him and they were happy because their plan was successful."
The quote in the story above is a motive for theme detetion, which states that the lies that were carried out by the community after they managed to trap Si Gumban into the coffin they had prepared. The proud and proud Gumban quickly got into the chest and couldn't get out again.

From the folklore analysis entitled Si Gumband, 6 data were obtained in quotations indicating motive, which formed the following series: Task, Task Completed, Lack, Lack Liquidate, Deceit, Deception.

\subsection{Analysis of the folklore motifame entitled Putri Kumalasari and Buluh Perindu}

"Until finally, King Kasmidun ordered the royal soldiers to deliver the competition to the whole community."

The quote from the story above is a motifeme task that states that a task must be carried out by the main character in King Kasmidun, who gives a contest to all of his people, and those who succeed in carrying it will get a prize. Men will be married off to their daughters, and if women will be adopted as children by the King.

"In this contest, both men and women all follow the competition except for children. Many people who went to Mount Mas-Mas were looking for the longing reed referred by the healer, but many people who participated in the competition were none of them could find the longing feathers referred to by the Abib."

The quotation from the story above is a completed motifeme task resulting from the fulfillment of the motive task. From the quote above, the community runs a competition that King Kasmidun has given. Both men and women are very enthusiastic about participating. However, none of these people managed to get the drug.

"Si Ujang also thought of participating in the competition. After the firewood was sold out, Ujang rushed to the mountains where the longing feathers referred to by the healer were."

The story quotation is a motive lack that indicates the characters' shortcomings or desires in the story that must be fulfilled. It can be in the form of dreams or thoughts of the characters or the character's goals. Ujang is a young man who lives alone. When selling firewood, he heard a dam competition wanting to get longing feathers on Mount Mas-Mas. The final wish shows that the story quoted above is a motif of lack.

"Then the Kasmidun King did not forget his promise in the competition. King Kasmidun married his daughter to the Ujang. Putri Kumala Sari and the Ujang live happily ever after in the kingdom of Antah Berantah."

The quote from the story above is a lack of liquidating motive, which states about part of the folklore, which indicates the fulfillment of the motive lack in folklore to fulfill the dreams or goals of the characters in one part of the story. The quote above shows Ujang's success in 
getting longing feathers, and Ujang also receives a gift according to what the King said, namely marrying Princess Kumalasari.

From the results of the analysis of the folklore entitled Putri Kumala Sari and Buluh Perindu, 4 data were obtained in the form of quotations indicating motive, which formed the following series: Task, Task Completed, Lack, and Lack Liquidate.

\section{CONCLUSIONS}

This research is research on the structure of the oral narrative stories of Tidung, North Kalimantan. This study focuses on the structure of the motifame in the folklore entitled The Origin of Mount Srilaki, Betawol, Si Gumban, Putri Kumalasari, and Buluh Perindu the chlorine study. The theory used in this study was the narrative structure developed by Dundes. It consists of a series of motifames such as lack feficiencies, and lack liquidates fulfillment of shortages, Tasks, (Task completed) Tasks fulfilled, ( Interdiction) Prohibition, (Violation) Violation, (Consequences) Consequences, (Attempt escape) Effort to save oneself, (Deceit) Deception, (Deception) Fraud.

Based on the results of research and discussion of the narrative structure of the folklore entitled The Origin of Mount Srilaki, Betawol, Si Gumban, Putri Kumalasari, and Buluh Perinduter, it consists of a series of motifames as follows (1) The Story of the Origin of Mount Srilaki consists of 10 series of Motifame, namely Interdiction, Violation, Consequences, Attempt Escape, Deceit, Deception, Task, Task Completed. (2) The Betawol story consists of 8 Motifame series, namely Lack, Lack Liquidate, Task, Task Completed, Task, Task Completed, Deceit, Detention. (3) The Betawol story consists of 6 Motifame series, namely Task, Task Completed, Lack, Lack Liquidate, Deceit, Detention. (4) The Betawol story consists of 4 series of Motifame, namely, Task, Task Completed, Lack, Lack Liquidate.

Based on the research that has been achieved, the researcher has several suggestions to convey to readers, namely:

a. For further researchers, research related to the Tidung Oral Story of North Kalimantan, apart from being studied with oral literature theory, can also be studied with other literary theories, namely comparative literature.

b. For future researchers, this study's results can be used as reference material in further research efforts that are considered relevant, especially those concerning the study of narrative structures in folklore.

\section{AUTHOR'S CONTRIBUTIONS}

Eva Apriani conceived and designed the research proposal and instrument. She also collected the data, performed the data analysis, and wrote the paper.

\section{ACKNOWLEDGMENTS}

My thanks go to the Ministry of Education and Culture of Indonesia, the Chancellor of the University of Borneo Tarakan, the Dean of the Faculty of Teacher Training and Education, and all those involved in this research. Especially the resource persons who were a lot of help in providing information, related cultural services. I especially thank you for being given research funds sourced from DIPA UBT. With this grant, it gives my spirit to explore the existence of local culture in Tarakan City, North Kalimantan.

\section{REFERENCES}

[1] Teeuw, Sastra dan Ilmu Sastra: Pengantar Teori Sastra, Jakarta: Dunia Pusat Jaya, 2010.

[2] Hutomo, L. R. Afdetis and Samsiani, Buku Belajar Mata Kuliah Folklor, Yogyakarta: Depublish, 2016.

[3] M. Okushima, Asal Usul Etnis Suku Tidoeng dan Penguasa yang Hilang di Pantai Borneo Timur Laut, Tarakan, 2004.

[4] . J. Danandjaja, Folklor Indonesia : Ilmu Gosip, Dongeng, dan lain-lain, Jakarta: Grafiti Pers, 2007.

[5] B. Lazuardi, Analisis Motifeme Pola Cerita IruiKon Dalam Cerita Rakyat Jepang, Surabaya:: Universitas Erlangga, 2014.

[6] Siswantoro, Metode Penelitian Sastra Analisis Struktur Puisi, Yogyakarta: Pustaka Pelajar, 2010.

[7] S. Y. Sudikan, Metode Penelitian Sastra Lisan, Lamongan: Pustaka Ilalang Group, 2015, p. 173.

[8] R. D. Pradopo, Beberapa Teori Sastra, Metode Kritik, dan Penerapannya, Yogyakarta: Pustaka Pelajar, 2011.

[9] Jumanus, Analisis Motif dan Leitmotif Dalam Kumpulan Cerita Rakyat Dayak Simpakng Kecamatan Simpang Dua Kabupaten Ketapang, Pontianak: Universitas Tanjungpura, 2017. 
[10] E. Bell, A. Bryman and . B. Harley, Business Research Methods, Oxford: Oxford University Press, 2018.

[11] P. Leavy, The Oxford Handbook of Qualitative Research: Oxford Handbooks Series, NY: New York: Oxford University Press, 2020.

[12] S. Inung, A. Eva and F. Siti , Bunga Rampai Cerita Lisan Tidung Kalimantan Utara, Jember: Pustaka Abadi, 2018. 